\title{
STUDY OF ANTI-VIRUS ACTIONS OF METABOLITES OF LACTOBACTERIA
}

D0I: 10.36740/WLek202007132

\author{
Svetlana V. Kalinichenko ${ }^{1,2}$, Kristina V. Melentyeva' ${ }^{1}$, Hans Manee ${ }^{2}$, Natalia V. Dubinina ${ }^{4}$, Natalia V. Zvereva ${ }^{1}$, \\ Inna I. Toryanik ${ }^{1,3}$, Natalia G. Popova ${ }^{3}$, Oleksandr V. Pakhomov ${ }^{5}$ \\ ${ }^{1}$ MECHNIKOV INSTITUTE OF MICROBIOLOGY AND IMMUNOLOGY NATIONAL ACADEMY OF MEDICAL SCIENCES OF UKRAINE, KHARKOV, UKRAINE \\ 2V. N. KARAZIN KHARKIV NATIONAL UNIVERSITY, KHARKOV, UKRAINE \\ ${ }^{3}$ KHARKIV NATIONAL MEDICAL UNIVERSITY, KHARKOV, UKRAINE \\ ${ }^{4}$ NATIONAL UNIVERSITY OF PHARMACY, KHARKOV, UKRAINE \\ ${ }^{5}$ INSTITUTE FOR PROBLEMS OF CRYOBIOLOGY AND CRYOMEDICINE OF THE NATIONAL ACADEMY OF SCIENCES OF UKRAINE, KHARKOV, UKRAINE
}

\begin{abstract}
The aim: of the work was to study the antiviral activity of the metabolites of the probiotic strain Lactobacillus rhamnosus GG (LGG or ATCC 53103) regarding clinical strains of enteroviruses (Coxsackie B-5, ECN021) isolated from the feces of intestinal infections.

Materials and methods: The object of the study was substrate-dependent cell cultures of HeLa, Vero, Hep-2 lines. The titer of the virus was determined by the presence of a clear cytopathic action (CPA) in the monolayer infected cells of the virus.

Results: Determination of the enteric virus infections activity in the culture fluid showed that in samples with the LGG metabolites, the infections activity of the clinical strains of enteroviruses decreased after 24 hours, at 1.5-1.7 $(p<0.05)$ times, and after 96 hours in 3,6 - 5,7 times $(p<0,01)$. the processing of cell cultures by metabolites in the amount of $0.3 \mathrm{mg} / \mathrm{ml}$ contributed to a decrease in the titer of viruses by $2.77 \pm 0.11 \mathrm{lg}$ TCDD50 / cm3, $2.83 \pm 0.11 \mathrm{lg}$ TCD50 / cm3 and $2.94 \pm 0.13 \mathrm{lg}$ TCD50 / cm3 for Vero, HeLa and Hep-2 line cells in 24 hours.

Conclusions: It has been experimentally determined that the maximum tolerated dose (MTD) of L. rhamnosus GG metabolites was $0.3 \mu \mathrm{g} / \mathrm{ml}$ for all cultures of cell lines. Determination of the antiviral activity of L. rhamnosus GG metabolites in clinical viruses of enteroviruses (Coxsackie B-5 and ECNO-21) showed a decrease in infection activity in 1.5-1.7 times, $(p<0.05)$ of clinical trials in clinical trials enteroviruses.
\end{abstract}

KEY WORDS: probiotic, cell cultures, antiviral activity, metabolites

Wiad Lek. 2020;73(7):1484-1488

\section{INTRODUCTION}

In recent years, the link between human microbiocenosis and the state of its immune system is an important direction for the research of Ukrainian and foreign scientists [1 - 5]. Special attention of researchers attracts such representatives of normal flora as Lactobacterium and Bifidobacteria and probiotic drugs on their basis. It is known that course application of oral probiotics containing lactobacilli, helps to increase the resistance of the human body to diseases not only bacterial but also viral etiology [6,7].

Today, probiotic drugs are considered to be the most promising means against many pathogens, since the leading role of normobiots of the human body in the preservation of its health has been proven. It is known that the anti-infective effect of probiotic drugs is due, first of all, to the antagonistic relationship between the probiotic strain and the pathogenic agent. Antagonism of probiotic strains is ensured by the production of biologically active substances (metabolites) that inhibit the development of pathogens [8].

As for the study of antiviral activity of probiotic drugs, research into such a plan requires an adequate model. To study the antiviral activity of probiotic drugs as a model for preclinical testing of drugs, biologically active substances, etc., the actual direction is the use of cell cultures, because they are able to specifically respond to the influence of biotic factors. Specificity, as a rule, manifests itself in the form of a cytotoxic effect, which is evaluated by the degree of morphological changes, morphological disorders and proliferative properties of cells.

\section{THE AIM}

The purpose of the work was to investigate the antiviral activity of metabolites of the probiotic strain Lactobacillus rhamnosus GG (LGG or ATCC 53103) on the clinical strains of enteroviruses (Coxsackie B-5, ECNO21) isolated from feces in patients with intestinal infections

\section{MATERIALS AND METHODS}

The object of the research was substrate-dependent HeLa, Vero, Hep-2 cell strains. They are morphologically epithelial cells by nature. 


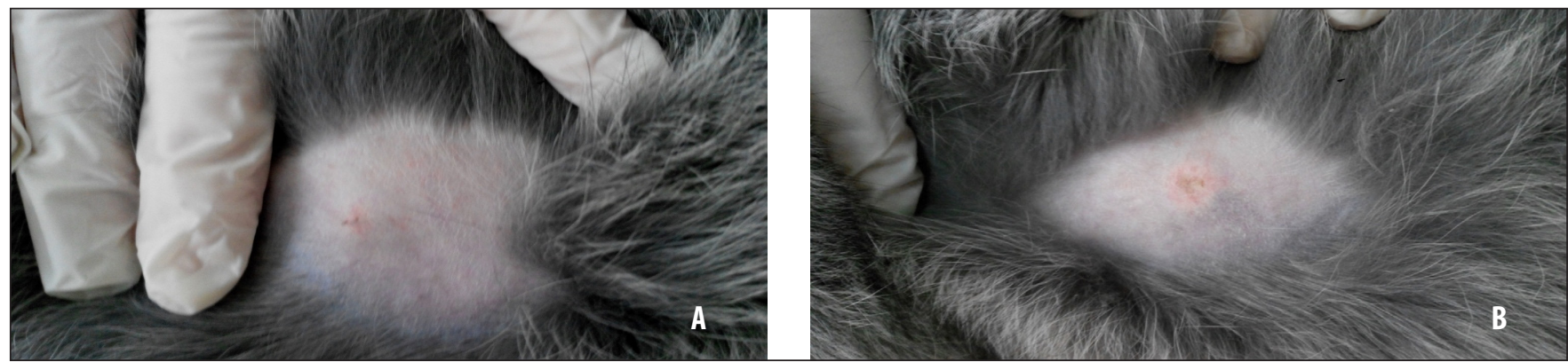

Figure 1. Skin reaction at the place of metabolite injection Notations: A - Hyperemia; B - Hyperemia and infiltrate.

\section{VIROLOGICAL METHODS}

Virus titer was evaluated based on the occurrence of cytopathic action (CPA) in the cells of culture monolayer such as appearance of round-shaped cells, detachment of the majority of the cells from glass surface and monolayer disruption. The titration of virus according to its CPA was based on determination of the largest dilution of the material contained the virus that could cause CPA in $50 \%$ of infected cell culture $\left(\mathrm{TCA}_{50}\right)$. Intensity of CPA was assessed by «plus system» (4+). Determination of TCA50 in the volume of the material taken for the single monolayer of cell culture was accomplished by Cerber's method. The Creber's equation for virus titer can be outlined in the following way:

$\lg \mathrm{TCA}_{50}=\mathrm{L}-\mathrm{d}(\mathrm{S}-0,5)$, where

$\mathrm{L}-\lg$ of the least dilution used during titration;

$\mathrm{D}$-the interval of $\mathrm{lg}$ between two consecutive dilutions;

$S$ - the sum of the proportions of positive test-units (namely, flasks with culture where CPA took place) at each dilution.

Antiviral activity was investigated using Vero, HeLa and Hep-2 strains. Their seeding concentration was $0,5 \times 10^{6} / \mathrm{ml}$. The monolayer of these cells was treated with metabolites of LGG with concentrations of $0.3,0.2,0.1 \mathrm{mg} / \mathrm{ml}$. Additionally, strains of Coxsackie B-5 and ECNO-21 viruses were introduced after 24 hours. Cytopathic action on cell state was checked every 24 hours with inverted microscope. Infectious activity titer was evaluated in experimental and control samples after 96 hours.

\section{MICROBIOLOGICAL METHODS OF INVESTIGATION}

Cell-free filtrates of cultural media obtained during L.rhamnosus GG cultivation were used as metabolites. The cell suspension of 24-hour L.rhamnosus GG culture with optical density of $1.0 \mathrm{McF}$ was used for preparation of these metabolites. $5 \mathrm{ml}$ of the prepared cell suspension were added to $45 \mathrm{ml}$ of nutritional broth with $1 \%$ glucose. Then the mixture was incubated for 72 hours at $37 \mathrm{C}$ under microairlift conditions. After that it was centrifuge at 3000 cycle/min (centrifuge ОПн-3 У 42, 1200G). for 30 minutes. The supernatant was collected and filtered through sterile net of $0.2 \mu \mathrm{m}$ in diameter (Vladipor, Russia). The procedure was repeated 3 times. These metabolites were checked for sterility.

\section{BIOCHEMICAL METHODS}

The level of protein nitrogen was determined in accordance with "The determination of protein nitrogen with Nessler's reagent by preliminary precipitation of the protein material in immunobiological drugs".

The method was based on the ability of Nessler's reagent to confer coloration during its reaction with free ammonia released after mineralization of protein containing products. $1 \mathrm{ml}$ of metabolites in centrifuge tube was added with $1 \mathrm{ml}$ of $20 \%$ trichloroacetic acid (TCA), carefully shaken and left for $18-20$ hours at $4-8 C^{\otimes}$. Then the samples were centrifuged for $30 \mathrm{~min}$ at 2000 cycles/min (centrifuge ОПн-3 У 42, 600G). The pellet was washed with $1 \mathrm{ml}$ of $10 \%$ TCA. The centrifugation was repeated. After that 0.1 $\mathrm{ml}$ of concentrated $\mathrm{H}_{2} \mathrm{SO}_{4}$ was added to the pellet. The samples were incubated in sandy bath for 10 hours at 190$200 \mathrm{C}^{\circ}$. A sample that contained only $\mathrm{H}_{2} \mathrm{SO}_{4}$ was used as a control sample. Then $9.9 \mathrm{ml}$ of distilled water was added to the mineralizate. After that $0.5 \mathrm{ml}$ of mineralizate was taken in case of sample with expected content of PNU of about 0.08 to $0.2 \mathrm{mg} / \mathrm{ml}$, diluted with distilled water to 9.5 $\mathrm{ml}$ and carefully mixed. Then $0.5 \mathrm{ml}$ of Nessler's reagent was added and mixed again. In case of the sample with expected content of PNU of about 0.2 to $0.4 \mathrm{mg} / \mathrm{ml}$ up to $1 \mathrm{ml}$ of mineralizate was used. Metabolites of Lactobacilli were tested for PNU for standardization. Their nitrogen content was adjusted to $0.1-0.3 \mathrm{mg} / \mathrm{ml}$. These doses were chosen to study sensitizing properties in laboratory animals (rabbits weighing from 1.5 to $2.0 \mathrm{~kg}$ )

The optical densities of all samples were measured at the wavelength of $400 \mathrm{~nm}$ against control. Curettes' width was $10 \mathrm{~mm}$. The calibration curve was drawn according to commercial standard sample of "Protein nitrogen content" (Pharmacea, Russia). The amount of protein nitrogen was calculated using equation bellow:

$$
\begin{aligned}
& \tilde{O}=\frac{a \times 10}{A \times B \times 1000}, \text { where } \\
& \text { X - PNU; }
\end{aligned}
$$

a - the amount of nitrogen according to calibration curve, $\mu$;

10 - mineralizate dilution;

A - the volume of investigated sample;

$\mathrm{B}$ - the volume of mineralizate, $\mathrm{ml}$;

1000 - the transition of $\mu \mathrm{g}$ to $\mathrm{mg}$; 
Table I. The degree of cell monolayer degeneration under the cell cultivation in growth medium supplemented with L. rhamnosus GG metabolites.

\begin{tabular}{|c|c|c|c|c|c|c|c|c|}
\hline \multirow{2}{*}{$\begin{array}{l}\text { Cells } \\
\text { lines }\end{array}$} & \multirow{2}{*}{$\begin{array}{c}\text { Time observation, } \\
\text { an hour }\end{array}$} & \multicolumn{7}{|c|}{ Amount of metabolites, mg / ml PNU } \\
\hline & & 0,3 & 0,2 & 0,1 & 0,05 & 0,025 & 0,0125 & 0,00625 \\
\hline \multirow{3}{*}{ HeLa } & 24 & - & - & - & - & - & - & - \\
\hline & 48 & + & + & \pm & - & - & - & - \\
\hline & 72 & ++ & ++ & ++ & \pm & - & - & - \\
\hline \multirow{3}{*}{ Vero } & 24 & - & - & - & - & - & - & - \\
\hline & 48 & - & - & - & - & - & - & - \\
\hline & 72 & \pm & - & - & - & - & - & - \\
\hline \multirow{3}{*}{ Hep-2 } & 24 & \pm & \pm & - & - & - & - & - \\
\hline & 48 & +++ & ++ & + & + & \pm & - & - \\
\hline & 72 & ++++ & +++ & ++ & ++ & + & \pm & - \\
\hline
\end{tabular}

\section{STATISTICAL METHODS}

Each experiment of the research was repeated 3 to 5 times. Statistical processing of data were carried out in accordance with the rules of the ordinary and alternative variation statistics.

\section{RESULTS AND DISCUSSION}

In the study of sensitizing properties of metabolites of lactobacilli in laboratory animals a dose of $0.1 \mathrm{mg} / \mathrm{ml}$ caused a questionable local allergic reaction (hyperemia of the skin), and a dose of $0.3 \mathrm{mg} / \mathrm{ml}$ caused a slightly positive reaction (the appearance of a blister with skin hyperemia around it) (Figure 1). Higher concentration of metabolites may cause necrosis at the place of injection meaning that such doses should be avoided.

The changes in morphology of cell culture (HeLa, Vero, Hep-2 were used) were used to assess cytotoxic action of probiotic strains.

First, the effect of sugar broth used for isolation of metabolites on adhesive properties and on the presence or absence of alterations in the monolayer of HeLa, Vero, Hep- 2 cell cultures was investigated. It was shown that the addition of 0.00625 to $0.5 \mathrm{ml}$ of sugar broth to $1 \mathrm{ml}$ of growth media did not alter the adhesive properties of HeLa, Vero, Hep-2 strains and monolayers' integrity.

The 24-hour action of probiotic L. rhamnosus GG metabolites on cell cultures resulted in no statistical change in HeLa, Vero, Hep-2 adhesiveness. After 48 and 72 hours of incubation all of the control cultures formed monolayers without any sings of degeneration. As far as the degree of degeneration of experimental cultures is concerned, the most stable to Lactobicili metabolites were Vero cells. Only 72-hour incubation in growth medium supplemented with $0.3 \mathrm{mg} / \mathrm{ml}$ metabolite of agent of influence affected some cells of this line. This corroborated the insensibility of this culture to the agent of influence (Table I).

HeLa cells had moderate sensitivity to lactobacilli metabolites. Some lesions were traced in $25 \%$ of these cells after 48-hour incubation in $1 \mathrm{ml}$ of growth media supplemented with a dose of metabolites that contained $0.3 \mathrm{mg} / \mathrm{ml}$ and $0.2 \mathrm{mg} / \mathrm{ml}$ of the agent of influence The addition of 0.1 $\mathrm{mg} / \mathrm{ml}$ L. rhamnosus GG metabolites to growth medium resulted in the breakdown of some cells of this line after 48 hours of incubation. Lesions were seen in $50 \%$ of Hela cells that were cultivated with $0.3,0.2$ and $0.1 \mathrm{mg} / \mathrm{ml}$ of metabolites after 72 hours. Some individual disrupted cells were found in growth media supplemented with $0.05 \mathrm{mg} /$ $\mathrm{ml}$ of metabolites.

The most sensitive to L. rhamnosus GG metabolites were Hep-2 cells. Some damaged cells were observed after 24 hours of incubation with 0.3 and $0.2 \mathrm{mg} / \mathrm{ml}$ of metabolites. Even the addition of as little dose as $0.025 \mathrm{mg} / \mathrm{ml} \mathrm{had} \mathrm{an} \mathrm{effect.} 100 \%$, $75 \%, 50 \%, 50 \%$ and $25 \%$ of these cells were damaged after 72 -hour incubation with $0.3,0.2,0.1,0.05$, and $0.025 \mathrm{mg} / \mathrm{ml}$ of $L$. rhamnosus GG metabolites, respectively. Moreover, some individual cells died in presence of $0.0125 \mathrm{mg} / \mathrm{ml}$.

The next phase of the research was elicitation of antiviral activity of metabolites of probiotic strain of L.rhamnosus GG.

It was found that clinical strains of enteroviruses could cause destruction in 50\% of experimental cells (HeLa, Vero, Hep-2) as early as 24 hours after the beginning of observation (Table II, III).

The first signs of enteroviral CPA (Cytopatological action) could be seen as HeLa cell breakdown after 48 hours of the HeLa monolayer treatment with 0.3 and $0.2 \mathrm{mg} / \mathrm{ml}$ PNU LGG metabolites. 50\% of these cells were damaged after 72 hours with respect to $100 \%$ in control. $50 \%$ of damaged cells of HeLa strain were detected after 48 hours of the monolayer treatment with $0.1 \mathrm{mg} / \mathrm{ml}$ PNU LGG metabolites and clinical enteroviral strains.

The treatment of Vero strain with LGG metabolites in concentration of $0.3 \mathrm{mg} / \mathrm{ml} \mathrm{PNU}$ resulted in appearance of the first signs of individual cell lesions after 48 and 72 hours under Coxsackie virus and ECNO-21 virus action, respectively. Lower doses of metabolites $(0.2$ and $0.1 \mathrm{mg} /$ $\mathrm{ml} \mathrm{PNU}$ ) led to appearance of the enteroviral CPA after 24 hours of introduction.

In the case of treatment of Hep-2 with LGG metabolites with 0.3 and $0.2 \mathrm{mg} / \mathrm{ml} \mathrm{PNU}$ the first signs of enteroviral CPA manifested after 24-48 hours. After 78 hours the destruction was observed in 50 and $75 \%$ of cells under ECNO-21 and Coxsacie virus action, respectively, when in control all of the cells (100\%) were damaged. The treatment 
Table II. Cell status under cytopathic action in the presence of the metabolites of LGG and the clinical strain ECN0-21.

\begin{tabular}{|c|c|c|c|c|c|}
\hline \multirow{2}{*}{$\begin{array}{l}\text { Cells } \\
\text { lines }\end{array}$} & \multirow{2}{*}{$\begin{array}{c}\text { Time } \\
\text { observation, } \\
\text { an hour }\end{array}$} & \multicolumn{4}{|c|}{ Amount of metabolites, mg / mI PNU } \\
\hline & & $\begin{array}{c}\text { K } \\
(\text { ECNO-21) }\end{array}$ & 0,3 & 0,2 & 0,1 \\
\hline \multirow{3}{*}{ Hela } & 24 & ++ & - & - & + \\
\hline & 48 & +++ & \pm & + & ++ \\
\hline & 72 & ++++ & ++ & ++ & +++ \\
\hline \multirow{3}{*}{ Vero } & 24 & ++ & - & + & + \\
\hline & 48 & +++ & - & ++ & ++ \\
\hline & 72 & ++++ & \pm & +++ & +++ \\
\hline \multirow{3}{*}{ Нер-2 } & 24 & ++ & + & + & ++ \\
\hline & 48 & +++ & ++ & ++ & +++ \\
\hline & 72 & ++++ & +++ & +++ & +++ \\
\hline
\end{tabular}

Table III. Cell status under cytopathic action in the presence of the metabolites of LGG and the Coxsackie virus B-5.

\begin{tabular}{|c|c|c|c|c|c|}
\hline \multirow{2}{*}{$\begin{array}{l}\text { Cells } \\
\text { lines }\end{array}$} & \multirow{2}{*}{$\begin{array}{c}\text { Time } \\
\text { observation, } \\
\text { an hour }\end{array}$} & \multicolumn{4}{|c|}{ Amount of metabolites, $\mathrm{mg} / \mathrm{ml}$ PNU } \\
\hline & & $\begin{array}{c}\text { K } \\
\text { (Coxsackie virus B-5) }\end{array}$ & 0,3 & 0,2 & 0,1 \\
\hline \multirow{3}{*}{ HeLa } & 24 & ++ & - & - & \pm \\
\hline & 48 & +++ & \pm & + & ++ \\
\hline & 72 & ++++ & ++ & ++ & +++ \\
\hline \multirow{3}{*}{ Vero } & 24 & ++ & - & + & + \\
\hline & 48 & +++ & \pm & ++ & ++ \\
\hline & 72 & ++++ & \pm & +++ & +++ \\
\hline \multirow{3}{*}{ Hep-2 } & 24 & ++ & \pm & \pm & + \\
\hline & 48 & +++ & + & + & ++ \\
\hline & 72 & ++++ & ++ & ++ & ++ \\
\hline
\end{tabular}

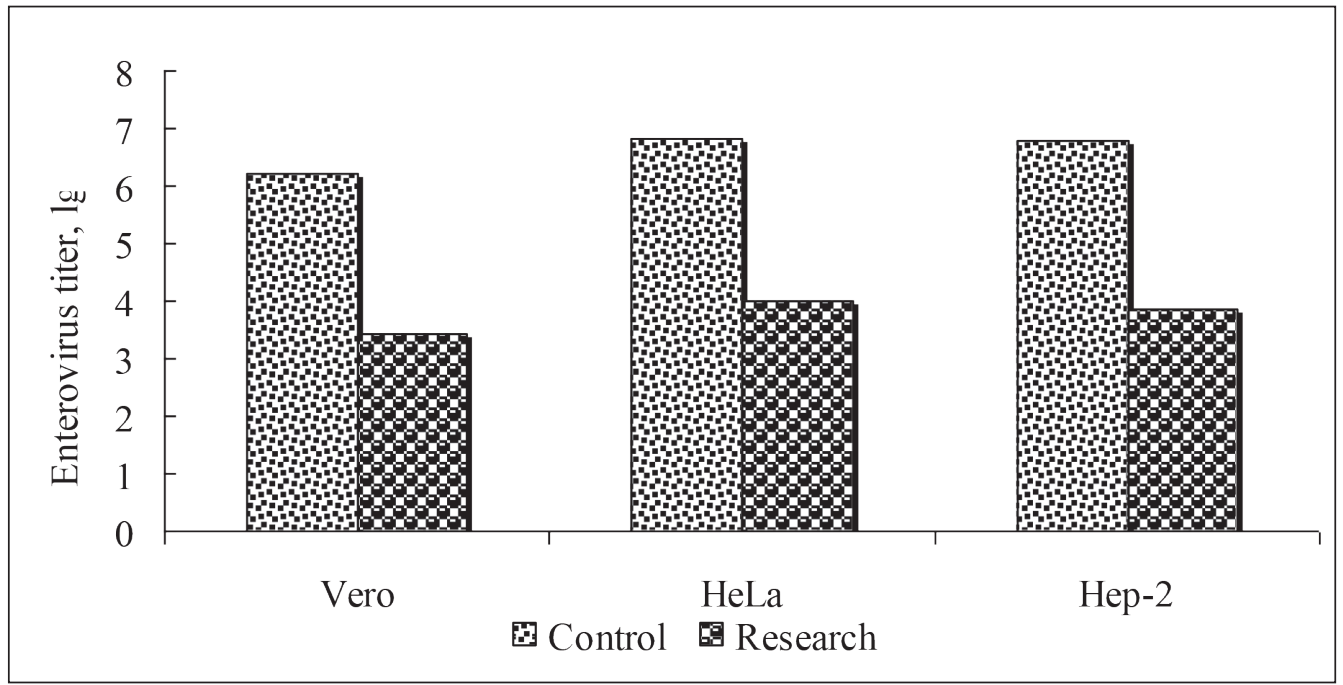

Figure 2. Enterovirus titer in different cell lines after 24 hours of infection. of Hep-2 strain with LGG metabolites that contain $0.1 \mathrm{mg} /$ $\mathrm{ml}$ PNU resulted in the breakdown of 50 and $75 \%$ of these cells under Coxsackie B-5 and ECNO virus actions.

The investigation of enteroviral infectious activity in cultural media showed that samples supplemented with LGG metabolites after 24 hours had 1.5-1.7 times lower viral activity $(\mathrm{p}<0.05)$. After 96 hours the viral activity decreased 3.6-3.7 times $(\mathrm{P}<0.01)$. The best results were obtained when maximum tolerated dose was used. The treatment of cell culture with metabolites that contained $0.3 \mathrm{mg} / \mathrm{ml}$ PNU favored virus titer decrease after 24 hours by $2,77 \pm 0,11 \mathrm{lg} \mathrm{TCA} 50 / \mathrm{cm} 3,2,83 \pm 0,11 \mathrm{lg} \mathrm{TCA} 50 / \mathrm{cm} 3$ and 2,94 $\pm 0,13 \mathrm{lg}$ TCA50/cm in Vero, HeLa and Hep-2, respectively (Figure 2 ). 
Thus, the protective and antiviral action of Lactobacillus rhamnosus GG metabolites has been represented with respect to HeLa, Vero, Hep-2 strains under Coxsackie and ECNO-21 viral infections.

Experimentally examined maximum tolerated dose (MTD) for all of these cultures came to $0.3 \mu \mathrm{g} / \mathrm{ml}$. Inhibiting doses that decreased the amount of viable cell to $50 \%$ $\left(\mathrm{ID}_{50}\right.$ ) were equal to $0.6 \mu \mathrm{g} / \mathrm{ml}$ for Vero strain and $0.5 \mu \mathrm{g} /$ $\mathrm{ml}$ for HeLa and Hep-2 strain.

Thus, it has been demonstrated that HeLa, Vero and Hep-2 possess different sensitivity to lactobacilli metabolite action. The most sensitive were HeLa and Hep-2. The effect was dose-dependent. These facts corroborate that these cell cultures can be used for the pre-clinical testing of metabiotic medications.

\section{CONCLUSIONS}

1. An estimation of the use of cell cultures (HeLa, Vero, Hep-2) for the study of the antiviral activity of the probiotic strain Lactobacillus rhamnosus GG (LGG or ATCC 53103) was performed. It has been experimentally determined that the maximum tolerated dose (MTD) of L. rhamnosus GG metabolites was $0.3 \mu \mathrm{g} / \mathrm{ml}$ for all cultures of cell lines.

2. Determination of the antiviral activity of L. rhamnosus GG metabolites in clinical viruses of enteroviruses (Coxsackie B-5 and ECNO-21) showed a decrease in infection activity in 1.5-1.7 times, $(\mathrm{p}<0.05)$ of clinical trials in clinical trials enteroviruses. Thus, the antiviral activity of L. rhamnosus GG metabolites has been experimentally determined.

\section{REFERENCES}

1. The Human Microbiome Project (HMP) Consortium. Structure, function and diversity of the healthy human microbiome. [Electronic resource]: Nature; 2012;486:207-214. - Access mode: https://www.nature.com/ articles/nature11234

2. Babenko L.P.Vplyv probiotychnykh shtamiv laktobatsyl ta bifidobakteriy na spektr mikrobioty ta imunolohichnu reaktyvnist' orhanizmu pri stafilokokoviy infektsiyi urohenetalnoho traktu [Influence of probiotic strains of lactobacillus and bifidobacteria on the spectrum of microbiota and immunological reactivity of the organism in staphylococcal infections of the urogenital tract]: Abstract. dissertation for obtaining the PhD of medical sciences: specialty. 03.00.07 «Microbiology». Kiev; 2015, p. 22 (In Ukrainian).

3. Dong H., Rowland I., Thomas L.V. et al. Immunomodulatory effects of a probiotic drink containing Lactobacillus casei Shirota in healthy older volunteers: European journal of nutrition 2013; 52(8):1853-1863.

4. Dong H., Rowland I., Thomas L.V. et al. Selective effects of Lactobacillus casei Shirota on T cell activation, natural killer cell activity and cytokine production: Clinical and experimental immunology: The journal of translational immunology 2010; 161(2): 378-388.
5. Schiffer C., Lalanne A.I., Cassard L. A strain of Lactobacillus casei inhibits the effector phase of immune inflammation: Journal of immunology 2011; 187(5): 26-46-2655.

6. Vrese M., Winkler P., Rautenberg P. Effect of Lactobacillus gasseri PA 16/8, Bifidobacterium longum SP 07/3, B. bifidum MF 20/5 om common cold episodes: a double blind, randomized, controlled trial: Clin Nutr 2005;24: 481-491.

7. Tubelius P., Stan V., Zachrisson A. Increasing work-place healthiness with the probiotic Lactobacillus reuteri: a randomizes, double-blind placebo-controlled study: Environ Health 2005; 4:25.

8. Kalinichenko S.V., Korotkikh 0.0., Tishchenko I.Y. Suchasni napryamky stvorennya ta udoskonalennya probiotykiv [Modern directions of creation and improvement of probiotics]. Ukrainian biopharmaceutical journal. 2016; 1 (42): 4-10. (In Ukrainian).

The work was carried out within the framework of scientific research work NAMS 133/2017 "Microecological aspects in different forms of acute viral hepatitis".

\section{ORCID and contributionship:}

SvetlanaV. Kalinichenko: 0000-0002-3482-9605 ${ }^{\mathrm{A}}$

KristinaV. Melentyeva: 0000-0003-4338-6655 B,D

Oleksandr V. Pakhomov: 0000-0002-7494-654X ${ }^{B}$

Natalia G. Popova: 0000-0002-2083-0402 ${ }^{\mathrm{C}}$

Hans Manee: 0000-0002-3854-1326 ${ }^{C}$

Natalia V. Dubinina: 0000-0002-0022-6830 ${ }^{E}$

Natalia V. Zvereva: 0000-0003-2941-7136 ${ }^{E}$

Inna I. Toryanik: 0000-001-6843-8808 ${ }^{F}$

\section{Conflict of interest:}

The Authors declare no conflict of interest.

\section{CORRESPONDING AUTHOR}

Kristina V. Melentyeva

Mechnikov Institute of Microbiology and Immunology

14-16 Pushkinskaya St., 61057 Kharkov, Ukraine

tel: +380979017354

e-mail:mkv0908@ukr.net

Received: 11.07 .2019

Accepted: 23.04 .2020

A - Work concept and design, B - Data collection and analysis, C - Responsibility for statistical analysis, D-Writing the article, $\mathbf{E}$-Critical review, $\mathbf{F}$ - Final approval of the article 